\title{
LETTER TO STATE DIRECTORS OF THE NATIONAL COUNCIL OF GEOGRAPHY TEACHERS
}

By Geonge J. Mn.I.eH

\author{
Secretary of the National Council
}

$\mathrm{T}$ HREE years ago last December the first step was taken to organize the National Council of Geography Teachers for the specific purpose of making the teaching of geography more effective in the schools of America. The National Council has been fully organized for two years and now has a membership of about 1000 . When it began its work there was only one state organization devoted to this purpose. State Directors are now at work in 40 states, and State Councils have been established in 20 states. Organizations will be completed in four or five other states during the coming year. Several states have established district councils for the purpose of holding special meetings in various parts of the respective states. The attendance at state meetings has varied from a few to approximately 1000 in New York, and several meetings have had an attendance of 200 to 300. This certainly shows an active interest in geography teaching.

The National Council has received hearty support and cooperation from the United States Commissioner of Education, The American Geographical Society, the Association of American Geographers, and the Journal of Geography. The American Geographical Society has contributed $\$ 200$ to foster the work of the National Council. It is largely through the use of these funds that the Council has been able to make such rapid progress.

The Council expects to take up one or more problems of national significance each year. A committee, of which Sumner W. Cushing, Salem, Mass., is chairman, is now at work on the problem of normal school geography. A preliminary report will be made at the meeting in Chicago next winter. This report will be of vital importance to every teacher of geography and especially to each state, as it should aid in bringing about an improvement in the preparation of teachers. Plan to be present at that meeting.

As State Directors, the success of the movement in your state rests in your hands. Several states have committees at work on important problems and their reports will soon be available. This material should be of great value to other workers. A few years of such constructive and cooperative efforts will produce results. Your Secretary wishes to suggest 
the following as problems that demand cooperation and united action, as they apply to nearly the whole country. You can assist the cause by starting a vigorous campaign in your state.

1. Establish a State Council if you have not already done so. When your organization is once established, you will have a working unit, and progress can be made. In some states "sectionalism" or "teacher politics" may be obstacles to be overcome, but continuous effort will bring success in the end. This has already been attained in some states where, at one time, success seemed hopeless. The more people you can get interested in reading, talking, and teaching geography, the sooner your state will get the benefit of this movement for better geography. The sooner you get public opinion aroused in favor of better geography teaching, the sooner geography will take its proper place in the school curriculum.

2. Promote publicity. This may be done by seeing to it that suitable speakers appear on the programs of all teachers' associations. State Directors are not finding this as difficult as they expected. In general the officers of state teachers' associations are ready to cooperate if your requests are possible of fulfilment. In some states a speaker has been secured for the "General Sessions" and then used in the geography section. This makes it possible to secure the financial assistance of the larger organization.

You may also give publicity to geography by directing the preparation of magazine articles for your state educational journals. Organized efforts along this line will bring excellent results and be a large factor in awakening interest. This is well illustrated by a series of articles on Home Geography by E. E. Lackey, of Wayne, Nebraska, in the educational journal of that State.

3. Geography in the Junior High School. The movement for the establishment of Junior High Schools is growing and now is the time to exert the best efforts of your organization in order to assure due consideration for geography. If you do not do so, geography will be crowded out by some other subject. School officials are inclined to welcome industrial, commercial, or economic geography. Here is a field that needs your immediate attention.

4. The better preparation of teachers. The majority of teachers of geography are prepared by normal schools. Some normal schools offer no regular courses in geography; in others the geography courses are taught by "whoever has a vacant hour"; in others, good courses in geography are offered but stu- 
dents are not required to take them. It seems incredible that normal schools are sending out graduates to teach geography who have had no real preparation.-but such is the regretable fact. The number of normal schools giving high grade work in geography is increasing. Your State Council can petition the 'normal schools of your state, requesting that adequate preparation in geography be required of all graduates who expect to teach the subject. You may do still more by inviting the superintendents of your state to cooperate in making the same request of the normal schools. If it is at all possible this work should be undertaken this year or early next fall, as it will prepare the way for the report of the National Council Committee on normal school geography. Cooperative effort in this matter should produce results in a short time.

5. Prepare a course of study. Most school officials will welcome the assistance that you can give in outlining the geography course, especially if you have no state course, or if the present one is inadequate. You can do a great deal to mould the character of the geography work in your state by the preparation of such a course. If you do not undertake to guide the geography work of your state some one else will do so and it may be one who is not trained in geography or in full sympathy with it.

Your Secretary realizes that he is suggesting large tasks that require considerable time and effort, but he believes that when they are completed better teaching of geography will reward your efforts. If every State Council will carry out these suggestions vigorously during the coming year, results will be secured immediately that it would otherwise require years to accomplish. The officers of the National Council wish to work with you in any way possible. Let them know how they may be of assistance. They believe the most effective work along these lines can be done by state organizations. No outsider can do it so well. No better time could be selected to illustrate the great importance of our subject. Knowledge of the countries of the world is now sought by every wide-awake American. The importance of geographic knowledge in the development of national life is now being well recognized. The fact that our great nation has thrown its vast resources into the world war has awakened interest in our own country and provided a "key" to public interest that should not be allowed to pass unused. Let us make the greatest possible use of this opportunity and advance the teaching of geography rapidly, until it stands at the fore-front in our school curriculum. Let us work energetically to make the coming year a notable one in the improvement of geography teaching. 